EETP Vol. 16, 2021, №. 5(63)

ISSN 1896-2327 / e-ISSN 2353-7787

DOI: 10.35765/eetp.2021.1663.04

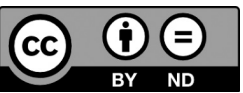

Nadesłano: 15.09 .2021

Zaakceptowano: 19.11.2021

Sugerowane cytowanie: (2021). Zdybel D. (2021). Kuchnia jako laboratorium edukacji STEM w przedszkolu - od eksperymentu do ścieżki uczenia się. „Edukacja Elementarna w Teorii i Praktyce", vol. 16, nr 5(63), s. 53-67. DOl: 10.35765/eetp.2021.1663.04

\title{
Kuchnia jako laboratorium edukacji STEM w przedszkolu - od eksperymentu do ścieżki uczenia się
}

\author{
Kitchen as STEM Laboratory in Preschool - from \\ an Experiment to the Learning Pathway
}

\begin{tabular}{|c|c|}
\hline SŁOWA KLUCZE & ABSTRAKT \\
\hline $\begin{array}{r}\text { STEM, edukacja } \\
\text { przedszkolna, } \\
\text { uczenie się przez } \\
\text { odkrywanie, } \\
\text { rozwiązywanie } \\
\text { problemów, ścieżka } \\
\text { edukacyjna }\end{array}$ & $\begin{array}{l}\text { Artykuł został napisany w ramach projektu Erasmus+ „Kitchen Lab } 4 \\
\text { Kids”. Celem prezentacji jest przedstawienie umiejętności STEM oraz } \\
\text { ich związków z myśleniem naukowym. Umiejętności STEM zostały } \\
\text { zdefiniowane jako ponadprzedmiotowe metakompetencje, stanowią- } \\
\text { ce podstawę procesu całożyciowego uczenia się, angażowane pod- } \\
\text { czas rozwiązywania ważnych, międzydyscyplinarnych problemów, } \\
\text { ale zarazem nienależące do żadnej konkretnej dyscypliny naukowej. } \\
\text { Umiejętności te są często opisywane jako umiejętności XXI wieku, } \\
\text { niezbędne dla funkcjonowania i rozwoju w nowoczesnym, nieprze- } \\
\text { widywalnym i podlegającym gwałtownym zmianom społeczeństwie. } \\
\text { Artykuł przekonuje, że rozwój takich umiejętności jest zakorzenio- } \\
\text { ny we wczesnym dzieciństwie i powinien być wspierany w eduka- } \\
\text { cji przedszkolnej z wykorzystaniem narzędzi i środków dostępnych } \\
\text { w każdej przedszkolnej kuchni. Typowe „kuchenne” umiejtności, }\end{array}$ \\
\hline
\end{tabular}

\footnotetext{
Artykuł sfinansowany ze środków EU. Wsparcie Komisji Europejskiej dla produkcji tej publikacji nie stanowi poparcia dla treści, które odzwierciedlają jedynie poglądy autora, a Komisja nie może zostać pociągnięta do odpowiedzialności za jakiekolwiek wykorzystanie informacji w niej zawartych. Badania przeprowadzone w ramach programu Erasmus+, projekt Kitchen Lab for Kids, numer grantu: 2018-1-PL01-KA201-050857
} 
wykorzystywane w toku gotowania i przetwarzania żywności, mają z natury naukowy charakter, ponieważ oparte są na rozumieniu fizycznych i chemicznych procesów i pojęć, np. odmierzaniu składników, rozumieniu proporcji między nimi, obserwowaniu zmian w stanie skupienia materii (przejścia od stanu stałego do ciekłego i odwrotnie), barwieniu żywności z wykorzystaniem naturalnych barwników, wykorzystywaniu fermentacji do pieczenia chleba etc. Rozumienie tych i podobnych im procesów może wspierać rozwój myślenia naukowego we wczesnym dzieciństwie.

\section{KEYWORDS ABSTRACT}

STEM, preschool education, learning by discovering, solving problems, learning pathway
The article has been written within the Erasmus+ project „Kitchen Lab 4 Kids". The aim of this presentation is to explain STEM skills and their interconnections with scientific thinking. STEM skills are described as interdisciplinary meta-competences underlying the life-long learning process, employed in the process of solving meaningful, interdisciplinary problems but not belonging to any particular scientific discipline. They are often referred to as XXI- century skills necessary for professional development in modern, unpredictable and rapidly changing societies. This paper argues that such skill development is deeply rooted in early childhood and should be supported in a preschool environment with the use of tools and means available in every preschool kitchen. Typical „kitchen” skills involved in cooking and food processing are scientific by nature because based on understanding the chemical and physical processes/ concepts, i.e. measuring the ingredients, understanding the proportions, mixing, observing the state of matter transformations (from solid to liquid and vice versa.), coloring the food with natural pigments, using the fermentation to bake the bread etc. Comprehending these and many similar processes can support scientific thinking development in early childhood.

\section{Wprowadzenie}

STEM to strategia edukacji integrującej elementy nauk przyrodniczych, technologii, inżynierii i matematyki, postrzegana jako efektywna odpowiedź na wyzwania, przed którymi staje edukacja w nowoczesnym, zdigitalizowanym, zmiennym i nieprzewidywalnym świecie. Choć idea nie jest nowa, wciąż jest mało spopularyzowana w polskiej pedagogice, między innymi z uwagi na trudność w dosłownym przetłumaczeniu akronimu STEM. Akronim ten tworzą terminy (White 2014: 4-6):

Science, czyli szeroko rozumiane nauki przyrodnicze, związane z badaniem natury i zachowaniem fizycznego uniwersum, np. biologia, chemia, fizyka, geologia, astronomia itp.; 
- Technology (technologia), rozumiana jako każde wykorzystanie w praktyce narzędzi technicznych, nie tylko cyfrowych, ale też tych znacznie prostszych, ułatwiających nam codzienne funkcjonowanie, takich, jak: młotek, wiertarka, nóż czy waga;

- Engineering, czyli inżynieria - grupa nauk zajmujących się praktycznym zastosowaniem ścisłej wiedzy naukowej w procesach projektowania maszyn, urządzeń, budynków, konstrukcji silników, mostów, pojazdów itp.;

- Mathematics, czyli szeroko definiowana matematyka, obejmująca nie tylko algebrę, arytmetykę czy geometrię, ale każdą próbę opisu świata za pomocą języka matematycznego i pojęć takich jak: liczba, ilość, kształt, przestrzeń (szerzej: White 2014; Kennedy, Odell 2014).

Głównym celem edukacji STEM jest ukształtowanie uczniów myślących twórczo i krytycznie, zdolnych do rozwiązywania złożonych, wielowarstwowych problemów w sposób elastyczny i niekonwencjonalny, z wykorzystaniem dostępnych w danym kontekście materiałów i sposobów działania. Można powiedzieć, że STEM jest metadyscypliną stawiającą sobie za cel usuwanie tradycyjnych barier między przedmiotami szkolnymi tak, by ukazać uczniom praktyczne zastosowanie wiedzy naukowej w życiu codziennym i uświadomić im, że nauka tworzona jest po to, by umożliwić człowiekowi głębsze rozumienie otaczającej go rzeczywistości (McClure 2017).

Celem artykułu jest prezentacja podejścia STEM, w którym kanwą aktywności dziecięcej stają się pojęcia żywności/ żywienia/ gotowania i przygotowywania posiłków. Jest to strategia edukacji przedszkolnej opracowana w ramach projektu Erasmus+ „Kitchen Lab for Kids” (KLab4Kids) - wykorzystująca kuchnię przedszkolną jako laboratorium do prowadzenia doświadczeń i eksperymentów naukowych pozwalających dzieciom oswajać pojęcia i procesy związane z przetwarzaniem żywności. W strukturze tekstu ujęto: krótki opis projektu, prezentację założeń edukacji STEM jako procesu uczenia się poprzez badanie oraz podsumowanie zawierające rekomendacje dla praktyki edukacyjnej w przedszkolu.

\section{Przedszkolna kuchnia jako laboratorium STEM - cele i założenia projektu}

Projekt Kitchen Lab for Kids jest rezultatem współpracy zespołu naukowców i dydaktyków z czterech krajów UE: Polski, Włoch, Irlandii oraz Hiszpanii. Jego głównym celem było zaprojektowanie i przetestowanie w praktyce spójnego zestawu narzędzi dydaktycznych służących do wprowadzenia edukacji STEM w przedszkolu. Zestaw ten, opublikowany na stronie projektu, obejmuje cztery zasadnicze elementy: a) zbiór doświadczeń, eksperymentów, zabaw i scenariuszy zajęć STEM-owych; b) ścieżki edukacyjne ilustrujące możliwości łączenia pojedynczych scenariuszy i eksperymentów 
w większe, spójne całości; c) przewodnik metodyczny dla nauczycieli; oraz d) wskazówki dla rodziców zainteresowanych realizacją zajęć STEM w warunkach domowych. Wyróżnikiem zaproponowanych materiałów jest ich tematyka, powiązana - pośrednio lub bezpośrednio - z żywnością i procesami jej przetwarzania. Taki dobór problematyki pozwala potraktować kuchnię (przedszkolną lub domowa) jako łatwo dostępne laboratorium wyposażone zarówno w sprzęty, proste narzędzia, jak i składniki (odczynniki) potrzebne do prowadzenia doświadczeń i eksperymentów naukowych. Sam proces przygotowywania posiłków: pieczenia, gotowania, smażenia, kiszenia i konserwowania, oparty jest na wykorzystaniu fizycznych właściwości różnych substancji oraz procesów chemicznych zachodzących podczas mieszania czy obróbki cieplnej składników. Im lepiej rozumiemy procesy naukowe leżące u podstaw przetwarzania żywności, tym skuteczniej i smaczniej gotujemy. W kuchennym laboratorium dzieci mogą poczuć się nie tylko jak początkujący kucharze, ale też jak naukowcy poszukujący odpowiedzi na pytania typu: W jakiej temperaturze ścina się jajko?; Dlaczego jabłka obrane ze skórki brązowieją i w jaki sposób można powstrzymać ten proces?; Skąd się biorą bąbelki gazu w napojach? Co się stanie, gdy zmieszamy ze sobą ocet i sodę?; Od czego zależy puszystość i kolor naleśników?; Czy jak dodamy więcej mąki, to naleśniki będą bardziej puszyste?; Dlaczego olej nie tonie w wodzie?; Jak zrobić jadalną butelkę do wody? itp. Tego typu pytania pobudzają ciekawość dzieci, zachęcając do eksperymentowania, które nie zawsze ma charakter prawdziwego gotowania, czasem staje się po prostu świetną zabawą, z wykorzystaniem najlepszych, bo „dorosłych” zabawek. Przy okazji dzieci uczą się zasad bezpieczeństwa pracy w kuchni, ćwiczą sprawne posługiwanie się najprostszymi narzędziami i urządzenia technicznymi dostępnymi w każdym domu (waga, miarka kuchenna, mikser, wałek, nóż itp.), a także poznają zasady zdrowego żywienia, odkrywają nowe smaki i zapachy, wielozmysłowo badają świat żywności, którą na co dzień - zdaniem wielu dorosłych - „nie wolno się bawić”. STEM-owe podejście do edukacji oferuje uczenie się poprzez zabawę, dla której materiałem stają się warzywa, owoce, przyprawy, składniki i narzędzia dostępne w każdej kuchni, łatwe do zdobycia i stosunkowo niedrogie.

Strategia edukacyjna KLab4Kids opiera się na uczeniu się przez odkrywanie i rozwiązywanie problemów. Aby proponowana dzieciom aktywność nabrała charakteru STEM-owego, ważne jest, by:

a) inspirowała myślenie problemowe, angażując takie operacje myślowe jak: dostrzeganie i formułowanie problemu, przewidywanie (stawianie hipotez), eksperymentalne weryfikowanie hipotez, formułowanie wniosków opartych na zgromadzonych dowodach empirycznych. Opisana procedura jest odzwierciedleniem metodologii badań przyrodniczych, wykorzystujących metodologię pozytywistyczną, czyli doświadczenie, obserwację i eksperyment jako podstawowe sposoby zbierania danych. Dla dzieci stanowi okazję do ćwiczenia precy- 
zji i logiki myślenia, dyscyplinowania procesów rozumowania, formułowania argumentów za i przeciw, rozumowania przyczynowo-skutkowego, myślenia krytycznego, odróżniania dowodu od opinii, informacji prawdziwej od fałszywej itp.;

b) wykorzystywała złożone problemy między- lub interdyscyplinarne, w naturalny sposób łączące elementy wiedzy z różnych dyscyplin (nauk przyrodniczych, technologii, inżynierii i matematyki) - zdaniem wielu badaczy wykorzystanie co najmniej dwóch odmiennych obszarów wiedzy jest warunkiem definicyjnym STEM (McClure et al. 2017). Największą wartość edukacyjną mają przy tym problemy o charakterze otwartym - nieposiadające jednej poprawnej odpowiedzi, dla których nie istnieje znany i wcześniej przećwiczony schemat działania. Problemy wymagające uruchomienia myślenia dywergencyjnego, wielotorowego, elastycznego;

c) proponowała okazję uczenia się w znaczącym dla dziecka, ważnym życiowo kontekście tak, by rezultaty uczenia się można było wykorzystywać w sytuacjach pozaszkolnych do zaspokajania ważnych potrzeb (tzw. meaningful learning - Katz 2010; Clement 2010). Przykładem może być funkcja, jaką pełni czytanie i pisanie w edukacji STEM - uczymy się pisać mimowolnie, „przy okazji”, np. zapisując wykorzystane w eksperymencie składniki, projektując słowno-rysunkową instrukcję wykonania zadania dla innych dzieci, przygotowując etykiety do próbek itp. W świadomości dziecka następuje zmiana priorytetów - nie uczymy się pisać na ocenę, ale piszemy dlatego, że jest to potrzebne do wykonania innego zadania. W ten sposób pisanie staje się narzędziem uczenia się, środkiem do realizacji ważnego celu, a nie celem samym w sobie;

d) wykorzystywała pracę zespołową i uczenie się we współpracy - w nowoczesnym społeczeństwie wiedzy współpraca specjalistów z różnych dziedzin jest naturalną konsekwencją komplikowania się wiedzy, która staje się zbyt złożona i zbyt rozległa dla pojedynczego człowieka. Członkowie zespołu wnoszą do działania różną wiedzę, ale też różne umiejętności, postawy, emocje, osobowości - uzupełniając się, stymulując i inspirując nawzajem, wyzwalając efekt synergiczny. Zespół dziecięcy jest także w naturalny sposób zróżnicowany pod względem zdolności, umiejętności, wiedzy, dzięki czemu dzieci nie tylko mają okazję uczyć się od siebie nawzajem, ale też poznawać własne możliwości i ograniczenia, rozpoznawać własne predyspozycje, w jednej sytuacji stawać się liderem grupy i nauczycielem dla innych, w innej zaś podejmować rolę szeregowego członka zespołu wykonującego polecenia innych. Uczenie się we współpracy sprzyja obserwowaniu myślenia innych, dyskutowaniu, negocjowaniu znaczeń, zderzaniu się różnych poglądów, wymianie argumentów, eksternalizacji własnej perspektywy i rozumienia cudzej (Bruner 2006); 
e) priorytetem uczynić dobrą zabawę - w wieku przedszkolnym uczenie się przez zabawę (zwłaszcza zabawę badawczą, problemowa) stanowi jeden z najważniejszych mechanizmów konstruowania wiedzy i umiejętności. Zabawa angażuje emocjonalnie, społecznie i poznawczo sprzyjając trwałości zdobywanych doświadczeń, motywuje do działania, rozbudza ciekawość, wyzwala pozytywne emocje.

Powyższe założenia przyświecały zaprojektowanym w Klab4Kids scenariuszom zajęć dla dzieci. Strukturę działań projektowych prezentuje poniższa tabela.

Tabela 1. Etapy realizacji projektu Kitchen Lab 4 Kids

\begin{tabular}{|c|c|}
\hline $\begin{array}{l}\text { Etapy realizacji projektu } \\
\text { Kitchen Lab } 4 \text { Kids }\end{array}$ & Działania i ich rezultaty \\
\hline $\begin{array}{l}\text { 1. Sondaż opinii nauczycieli } \\
\text { przedszkoli w czterech krajach } \\
\text { UE na temat celów, możliwości } \\
\text { i barier w edukacji STEM na } \\
\text { poziomie przedszkola }\end{array}$ & $\begin{array}{l}\text { Idea edukacji STEM jest najbardziej rozpowszechniona } \\
\text { w Irlandii i Włoszech, słabiej znana w pozostałych krajach. } \\
\text { Jednak wszędzie przeszkody w prowadzeniu tego typu } \\
\text { edukacji na poziomie przedszkola postrzegane są podobnie: } \\
\text { - brak edukacji STEM w podstawach programowych } \\
\text { przedszkola; } \\
\text { - przeładowany program, nakierowany na osiągnięcia } \\
\text { akademickie (czytanie, pisanie, matematykę); } \\
\text { - brak funduszy na zakup materiałów do doświadczeń } \\
\text { i eksperymentów; } \\
\text { - brak dodatkowego nauczyciela/ asystenta zapewniającego } \\
\text { bezpieczeństwo podczas zajęć; } \\
\text { - nieprzyjazna postawa innych nauczycieli wobec innowacji }\end{array}$ \\
\hline $\begin{array}{l}\text { 2. Zebranie przykładów } \\
\text { dobrych praktyk: doświadczeń } \\
\text { i eksperymentów, gier i zabaw } \\
\text { ilustrujących zastosowanie } \\
\text { edukacji STEM z wykorzystaniem } \\
\text { kuchni i żywności }\end{array}$ & $\begin{array}{l}\text { Opis scenariuszy zajęć dostosowanych do możliwości } \\
\text { dzieci w wieku przedszkolnym - dostępny w } 6 \text { językach } \\
\text { na stronie projektu: http://kitchenlab4kids.eu/?page_id=9 } \\
\text { 51\#TeachingSetSelectLanguages }\end{array}$ \\
\hline $\begin{array}{l}\text { 3. Testowanie i doskonalenie } \\
\text { zebranych materiałów przez } \\
\text { wspólnotę uczącą się - } \\
\text { wspólnotę nauczycieli i studentów } \\
\text { edukacji przedszkolnej }\end{array}$ & $\begin{array}{l}\text { Dzięki zaangażowaniu wspólnoty zebrane materiały zostały } \\
\text { poddane weryfikacji - sprawdzone i ocenione, zilustrowane } \\
\text { instrukcjami filmowymi, także wzbogacone o nowe } \\
\text { pomysły doświadczeń i eksperymentów. Pracę wspólnoty } \\
\text { dokumentowano: } \\
\text { - na Facebooku: https://www.facebook.com/ } \\
\text { KitchenLab4Kids-109904723897139; } \\
\text { - oraz na YouTube: https://www.youtube.com/channel/ } \\
\text { UCA7UdkiVACILTQ_hdLFJuyA }\end{array}$ \\
\hline $\begin{array}{l}\text { 4. Projektowanie i weryfikacja } \\
\text { ścieżek edukacyjnych }\end{array}$ & $\begin{array}{l}\text { Wyodrębniono i opisano } 4 \text { typy ścieżek edukacyjnych, które } \\
\text { następnie zostały przetestowane w praktyce edukacyjnej - } \\
\text { z udziałem dzieci i studentów: } \\
\text { http://kitchenlab4kids.eu/?page_id=4773/\#Sciezki-uczenia-sie }\end{array}$ \\
\hline
\end{tabular}




\begin{tabular}{|l|l|}
\hline \multicolumn{1}{|c|}{$\begin{array}{c}\text { Etapy realizacji projektu } \\
\text { Kitchen Lab 4 Kids }\end{array}$} & \multicolumn{1}{c|}{ Działania i ich rezultaty } \\
\hline $\begin{array}{l}\text { 5. Scalenie wszystkich } \\
\text { zaprojektowanych materiałów } \\
\text { w formie „skrzynki” z narzędziami } \\
\text { edukacyjnymi dla nauczycieli } \\
\text { i edukatorów }\end{array}$ & $\begin{array}{l}\text { Zestaw narzędzi edukacyjnych (tzw. Toolkit) zawiera } \\
\text { nie tylko scenariusze zajęć i ścieżki edukacyjne, ale też } \\
\text { przewodnik - wskazówki metodyczne dla wszystkich } \\
\text { zainteresowanych edukacją STEM w przedszkolu; } \\
\text { bibliografię literatury dostępnej w różnych językach; raport } \\
\text { z przeprowadzonych badań oraz serię filmowych instrukcji } \\
\text { ułatwiających przeprowadzenie doświadczeń STEM zarówno } \\
\text { w środowisku przedszkolnym, jak i domowym. }\end{array}$ \\
\hline
\end{tabular}

Źródło: opracowanie własne na podstawie projektu Kitchen Lab for Kids, numer grantu: 2018-1-PL01-KA201-050857

\section{STEM jako strategia uczenia się przez odkrywanie - od eksperymentu do ścieżki edukacyjnej}

Ścieżka uczenia się to sekwencja materiałów (aktywności/ scenariuszy zajęć), które zostały logicznie powiązane ze sobą tak, by umożliwić dzieciom opanowanie określonego tematu, pojęcia lub umiejętności. Ścieżka to propozycja drogi, jaką powinno przejść uczące się dziecko, by przekształcić posiadaną - często przedpojęciową i naiwną - wiedzę w rozumowanie o charakterze naukowym. Ścieżki uczenia się w prezentowanym projekcie zostały zaprojektowane jako elastyczne narzędzie pracy, by umożliwić nauczycielowi spojrzenie na edukację STEM jako długotrwały proces, wzorowany na metodzie projektów, a nie pojedyncze zdarzenie czy eksperyment (Clement 2000). Jeśli pomyślimy o ścieżkach uczenia się jako podejściu projektowym, to łatwo zrozumieć, dlaczego każda ścieżka ma specyficzne cele, wewnętrzną, logicznie uporządkowaną strukturę opartą na sugerowanej kolejności działań i zajęć dla dzieci, a także własną ewaluację, podporządkowaną tematowi. Z metodycznego punktu widzenia podstawą konstrukcji ścieżki uczenia się można uczynić określony temat, ale też pojęcie naukowe lub umiejętność. W projekcie Klab4Kids zaproponowano cztery typy ścieżek:

A) Ścieżki tematyczne, np. „W laboratorium piekarza”, „Nauka o słodyczach najpierw eksperymentuj, potem jedz!";

B) Ścieżki oparte na umiejętnościach - poświęcone rozwijaniu wybranej grupy zdolności STEM, np. „Uczymy się współpracować w zespole”, lub „Uczenie się jak obserwować i odkrywać”; 
C) Ścieżki oparte na dyscyplinach STEM, np. „M w STEM, czyli zastosowanie matematyki w życiu codziennym”; „STEM - Eksperymentalne projektowanie";

D) Ścieżki poświęcone rozwijaniu pojęć naukowych, np. „Zmiana stanu skupienia - ciała stałe i ciecze”, „Konstruowanie i myślenie w 3D - Jak zostać inżynierem”, „Badamy gęstość cieczy - w naturze i w kuchni” oraz „Co to jest osmoza?".

Aby wyjaśnić wartości edukacyjne ścieżek uczenia się, warto posłużyć się konkretnym przykładem - poniżej przedstawiono strukturę ścieżki „Dwutlenek węgla - przyjaciel czy wróg?”, poświęconej badaniu właściwości i praktycznych zastosowań CO2.

\section{Tytuł ścieżki}

„Dwutlenek węgla - przyjaciel czy wróg?”

http://kitchenlab4kids.eu/?page_id=4471

\section{Cele ogólne:}

- Wprowadzenie pojęć: gaz, dwutlenek węgla, emisja gazów, fermentacja.

- Kształtowanie rozumienia procesów przetwarzania żywności z udziałem dwutlenku węgla (fermentacja drożdży, produkcja napojów gazowanych).

- Wzmacnianie ciekawości i motywacji do uczenia się.

\section{Zamierzone rezultaty uczenia się}

Dziecko:

- wyjaśnia rolę CO2 w procesie pieczenia ciastek;

- wyjaśnia, w jaki sposób powstają bąbelki w napojach gazowanych;

- rozpoznaje (przewiduje) wybuchową naturę CO2 w niektórych mieszaninach substancji;

- nazywa substancje kuchenne, które mogą zostać użyte do wykonania eksperymentów z CO2.

\section{Struktura ścieżki uczenia się}

Wprowadzenie do zajęć - ewaluacja początkowa, aktywizowanie uprzedniej wiedzy dzieci.

Wyjaśnienie pojęcia 'gaz'. Proponowane pytania:

- Jakie znacie stany skupienia materii?

- Co to jest gaz - po czym poznajemy, że jakaś substancja jest gazem?

- Jakie znacie rodzaje gazów?

- Gdzie można zaobserwować gaz?

- Do czego można wykorzystać znane nam rodzaje gazów? 


\section{Krok I}

Wprowadzenie pojęcia „dwutlenek węgla” jako gaz - obserwowanie procesu wydzielania się CO2 i jego skutków.

- Doświadczenie 1: Ocet, soda i inne wybuchy - dzieci najpierw obserwują, co się stanie, jeśli do sody dolejemy octu. A potem testują, czy siła wybuchu zależy od ilości wykorzystanej sody (do kolejnych naczyń z tą samą ilością octu dosypują 1, 2, 3, 4, 5 oraz 6 łyżeczek octu).

- Doświadczenie 2: Gaszenie świeczki za pomocą CO2 - dzieci sprawdzają, czy za pomocą CO2 uda się zgasić płomień świeczki („wylewając” dwutlenek węgla wyprodukowany za pomocą octu i sody). Wniosek: CO2 można wykorzystać do produkcji gaśnic przeciwpożarowych.

\section{Krok II}

Badanie przydatności CO2 w kuchni - proces fermentacji drożdży i produkcji lemoniady. Badanie skutków działania CO2 dla smaku i wyglądu potraw

- Doświadczenie 3: Musująca lemoniada - wyjaśnienie istoty napojów gazowanych i obserwowanie ich produkcji. Dzieci przygotowują domową wersję lemoniady - do szklanki z zimną wodą wlewamy sok z samodzielnie wyciśniętej cytryny, lekko słodzimy. A następnie sprawdzamy, co się stanie, gdy do tak przygotowanej mieszaniny dosypiemy 1 łyżeczkę sody oczyszczonej. Czym są bąbelki w naszym napoju?

- Doświadczenie 4: Biologia chleba - badanie właściwości drożdży. Chleb w torebce. Obserwowanie roli CO2 w procesie produkcji ciast. Dzieci najpierw badają wielozmysłowo właściwości drożdży świeżych i suchych (porównują, smakują itp.), a następnie obserwują etapy fermentacji drożdży, rozrabiając je z wodą i cukrem. Szukają przy tym odpowiedzi na pytania: Co się dzieje?; Jak zmienił się zapach drożdży, co czujecie?; Co to są za bąbelki?; Skąd się wzięły?; Jak nazwać taki proces? Na koniec wykorzystują przygotowane drożdże do zagniecenia ciasta na chleb.

- Doświadczenie 5: Dlaczego ciasto „plaster miodu” jest pełne bąbelków? Dzieci przygotowują miksturę z wody, cukru, syropu klonowego oraz sody oczyszczonej (w podanych przez nauczyciela proporcjach), zagotowują ją, energicznie mieszając, a następnie wylewają na blachę i obserwują proces zastygania ciasta. Łamią ciasto na kawałki i szukają odpowiedzi na pytanie: Skąd się wzięły bąbelki w naszym cieście? Jak powstały?

\section{Krok III}

Podsumowanie: Dwutlenek węgla - gaz pożyteczny czy groźny?

- Doświadczenie 6: Domowa Lampa Lawa - dzieci najpierw badają, co się stanie, gdy do wody (zabarwionej barwnikiem spożywczym) dolejemy 
oleju, stawiają hipotezy, obserwują, że olej nie rozpuścił się w wodzie, tylko utworzył odrębną warstwę na jej powierzchni. A następnie do tak przygotowanej mieszaniny wrzucają tabletkę musującą (np. Alka Selzer lub witaminę C) i obserwują rezultat. Tabletka rozpuszczając się, produkuje dwutlenek węgla, który uwalnia się w postaci bąbelków gazu i wędruje poprzez warstwę wody.

- Doświadczenie 7: Jak nadmuchać balon drożdżami? - rodzaj wyzwania, w którym dzieci dostają 1 pustą butelkę, 1 balon oraz zestaw różnorodnych materiałów: drożdży świeżych i suchych, wody ciepłej i zimnej, mąki, oleju, octu itp. Zadaniem zespołów jest opracowanie przepisu na mieszaninę, która najszybciej napompuje balon. Mieszaninę wykonujemy w osobnym naczyniu, przelewamy do pustej butelki, na szyjkę butelki nakładamy balon i obserwujemy rezultaty, mierząc czas pompowania.

\section{Ewaluacja końcowa}

A. Wykonanie mapy myśli „Czego dowiedzieliśmy się o dwutlenku węgla (CO2) - w celu uświadomienia sobie przez dzieci posiadanej wiedzy, jej kompletności i ewentualnych obszarów nierozpoznanych (kolejnych pytań i kierunków badania tematu).

B. Głosowanie na najbardziej ekscytujący eksperyment.

Konstrukcja ścieżek edukacyjnych opiera się na przekonaniu, że na uczenie się małych dzieci należy patrzeć jak na długotrwały proces oparty na wielokrotnym powtarzaniu tych samych lub podobnych doświadczeń (Katz 2010) - ta powtarzalność umożliwia ukształtowanie się w umyśle dziecka pewnych schematów myślenia i działania. Ścieżka uczenia się zapewnia też transfer, czyli przeniesienie wiedzy i umiejętności zdobytych w jednej sytuacji uczenia się na inną sytuację, zastosowanie ich w toku innego eksperymentu, wykorzystanie w innym zadaniu czy otoczeniu. Dzięki temu dziecko dostrzega przydatność zdobywanej wiedzy, ma okazję do jej sprawdzania, utrwalenia i pogłębiania w działaniu. Może drążyć temat stopniowo, odkrywając coraz to nowe pola eksploracji, nowe pojęcia, nowe obszary doświadczeń. W toku zajęć naturalne dziecięce zdolności rozumowania zostają wplecione w uporządkowany cykl myślenia problemowego, a powtarzanie tych samych operacji poznawczych w różnych sytuacjach sprzyja kształtowaniu się umiejętności myślenia i uczenia się. Kolejne aktywności STEM stają się w ten sposób szczeblami rusztowania poznawczego (Bruner 2006). 
Zgodnie z powyższym założeniem, cykl uczenia się przez odkrywanie w zaproponowanych przez Klab4Kids ścieżkach edukacyjnych obejmuje pięć zasadniczych etapów (Dilek et al. 2020):

1. zaangażowanie - zbudowanie przez nauczyciela sytuacji problemowej, której celem jest pobudzenie ciekawości dzieci, zmotywowanie ich do działania, zainspirowanie. W konsekwencji następuje uświadomienie sobie przez dzieci obszarów własnej wiedzy i niewiedzy, dostrzeżenie problemu i sformułowanie pytania badawczego. W opisanej powyżej ścieżce edukacyjnej etapowi temu odpowiada wprowadzenie i początek doświadczenia nr 1;

2. eksploracja - naturalną konsekwencją sformułowania pytania problemowego powinno być stawianie hipotez, przewidywanie możliwych odpowiedzi (nauczyciel zapisuje odpowiedzi dzieci na specjalnie przygotowanej karcie, a następnie dzieci przeprowadzają badanie - doświadczenie lub eksperyment, którego celem jest zweryfikowanie postawionych hipotez i znalezienie rozwiązania). W toku eksperymentowania dzieci zgłębiają badane pojęcie, doświadczają go wielozmysłowo, odkrywają nowe zjawiska i procesy;

3. wyjaśnianie - rezultatem przeprowadzonych badań powinno być samodzielne sformułowanie uzasadnionych - czyli popartych zdobytymi dowodami empirycznymi - wniosków, uświadomienie sobie istoty pojęcia, relacji między pojęciami lub procesami. Dzieci wyjaśniają, co zaobserwowały i czego się nauczyły, uczą się uzasadniania własnych wniosków, przyswajają fachową terminologię. W opisanej powyżej ścieżce uczenia się etapom eksploracji i wyjaśnienia odpowiada doświadczenie nr 1 ;

4. elaboracja (dopracowanie) - jej istotą jest zastosowanie zdobytej w poprzednim etapie wiedzy pojęciowej w nowym kontekście, czyli w nowym doświadczeniu/ eksperymencie, który ponownie rozpoczyna się od postawienia problemu, formułowania hipotez oraz ich testowania. Jednak z uwagi na wcześniej zdobyte doświadczenia, dzieci dokonują teraz transferu nowego pojęcia na nowe warunki działania, pogłębiają rozumienie tego pojęcia, obserwują jego nowe właściwości/ relacje/ procesy, w jakich uczestniczy. Pojęcie zostaje utrwalone poprzez powtarzanie go w kilku kolejnych zadaniach badawczych. W opisanej powyżej ścieżce temu etapowi odpowiadają doświadczenia 2-7;

5. ewaluacja - dzieci oceniają własną wiedzę, uświadamiają sobie rezultaty własnego uczenia się (wskazując obszary własnej wiedzy, jak i niewiedzy czy niepewności), wyznaczają cele przyszłego uczenia się. W strukturze opisanej ścieżki edukacyjnej temu etapowi odpowiada ewaluacja końcowa.

Jedną z kluczowych wartości ścieżek edukacyjnych jest wspieranie rozwoju dziecięcej zdolności do samodzielnej regulacji własnego uczenia się, uświadamiania sobie prawidłowości tego procesu (Kuhn, Dean 2004) (wykres 1). Dzieci spontanicznie 
naśladują czynności nauczyciela, powtarzają zadawane przez niego pytania, przenosząc je na nowe sytuacje uczenia się. Utrwala się sekwencja pytań kierujących myśleniem problemowym: od postawienia problemu (Co się stanie, gdy...?), przez formułowanie hipotez (Jak myślicie/ Kto ma inny pomysł?), projektowanie eksperymentów i prowadzenie badań (Jak to sprawdzić? Co możemy zrobić?), aż po formułowanie wniosków (Co zaobserwowaliśmy? Co się stało i dlaczego? Jak to wyjaśnić? Dlaczego tak myślicie, jakie mamy dowody?). Wielokrotne powtarzanie takiej sekwencji pytań, ujętej w ramy działania projektowego, sprzyja uruchamianiu refleksji nad własnym myśleniem (refleksji metapoznawczej), która jest powszechnie postrzegana jako rdzeń każdego uczenia się, determinujący jego jakość i rezultaty. Nadaje bowiem uczeniu się charakter strategiczny, poddając je rygorom świadomej kontroli. „Może tym samym wzmacniać potencjał intelektualny jednostki, dostarczając narzędzi aktywnego zarządzania własną wiedzą - dzięki świadomości metapoznawczej uczenie się nabiera charakteru autoregulacyjnego i może być dowolnie kształtowane przez jednostkę" (Zdybel 2015).

Wykres 1. Samoregulacja uczenia się w cyklu badawczym ścieżki edukacyjnej

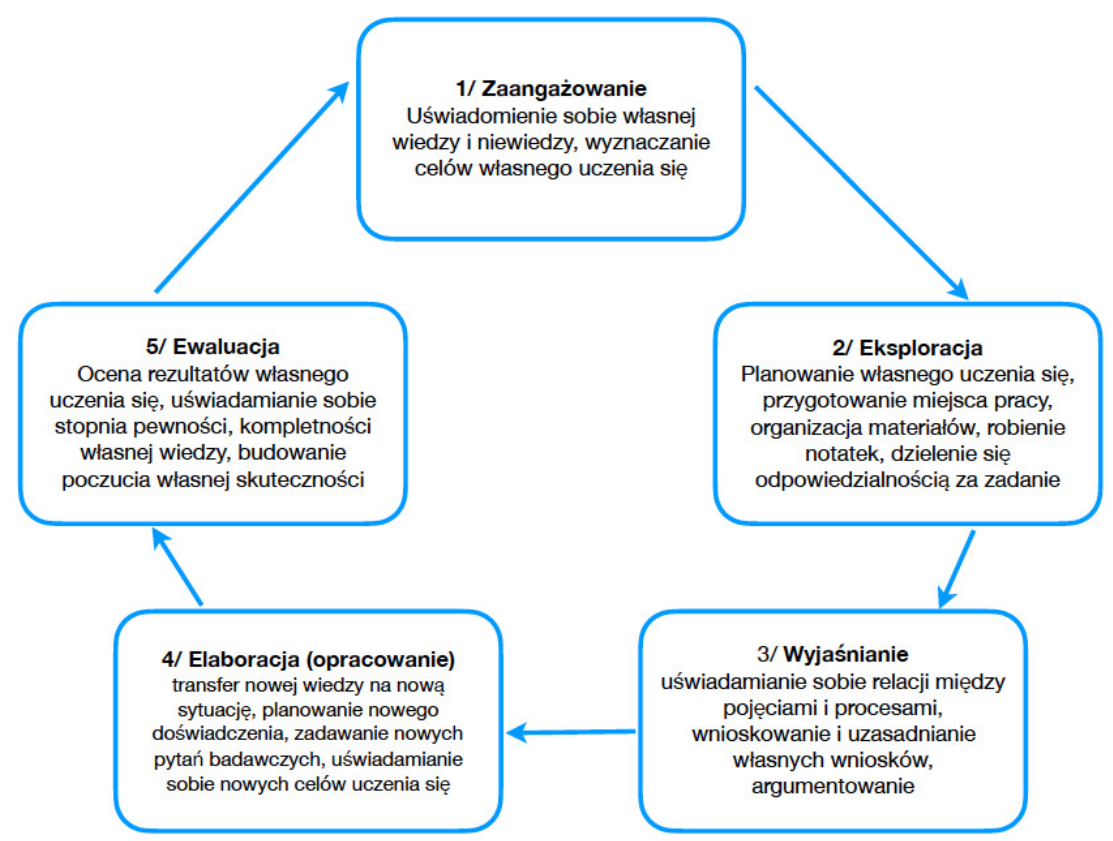

Źródło: opracowanie własne na podstawie Dilek et al. 2020. 


\section{Podsumowanie - o standardach edukacji STEM w przedszkolu}

Edukacja STEM przywiązuje dużą wagę do kształtowania u dzieci pozytywnego obrazu samego siebie jako podmiotu uczącego się, zdolnego do pokonywania trudności, naprawiania własnych błędów, osiągania sukcesów. Wiele badań wskazuje, że entuzjazm wobec poznawania nauk ścisłych, zwłaszcza matematyki, który można obserwować u dzieci przedszkolnych, szybko przeradza się w niechęć i lęk w konfrontacji z wymaganiami szkolnymi (Gruszczyk-Kolczyńska 1997; Clements, Sarama 2016).

Poczucie sprawczości i skuteczności własnej, rozumiane jako dziecięce przekonanie, że „dam sobie radę”, „potrafię" jest niezbędnym warunkiem efektywnego uczenia się zwłaszcza w przypadku przedmiotów ścisłych (Kuhn, Dean 2004). Pozwala niwelować lęk przed nowymi, nieznanymi (nieprzećwiczonymi wcześniej) zadaniami, podchodzić do uczenia się z otwartością, odważnie podejmować wyzwania intelektualne. Jak wskazuje Anna Brzezińska, pozytywne doświadczenia w uczeniu się pozwalają budować zasoby i kompetencje osobiste dziecka, takie jak zaufanie do siebie i świata, autonomia i inicjatywa (Brzezińska, Matejczuk, Nowotnik 2012). „Dziecko buduje pełne nadziei przekonania na temat świata i swojego miejsca w nim, nabiera poczucia, że jest w stanie sprostać różnym zadaniom, a świat i inni ludzie będą je wspierać w realizacji jego zamierzeń" (Brzezińska, Matejczuk, Nowotnik 2012: 9). Z kolei niska samoocena czy brak poczucia własnej skuteczności mogą spowodować, że dziecko w ogóle nie podejmie zadania, tzn. nie będzie skłonne inwestować posiadanych zasobów intelektualnych w działanie, w którego powodzenie nie wierzy - wycofuje się i zamyka w sobie, wychodząc z sytuacji uczenia się z poczuciem porażki osobistej (Kanevsky, Geake 2004: 185). Dlatego tak ważne jest zapewnienie małym dzieciom pozytywnych doświadczeń w uczeniu się. Jak podkreśla Lilian Katz, na etapie edukacji przedszkolnej należałoby mówić raczej o „standardach pozytywnych doświadczeń w uczeniu się", niż „standardach osiągnięć” akademickich (czyli zdobywania konkretnych informacji czy umiejętności). Wśród doświadczeń STEM niezbędnych dzieciom w wieku przedszkolnym L. Katz wymienia następujące:

dzieci powinny często przeżywać sytuacje (Katz 2010: 6):

- bycia intelektualnie zaangażowanym, skoncentrowanym na zadaniu (pochłoniętym wykonywaną praca);

doświadczania zaufania do własnego intelektu i własnych pytań, uznania dla własnej pracy i wysiłku intelektualnego;

podejmowania wyzwań intelektualnych - czyli zadań wymagających wysiłku myślowego, dla których nie ma prostych, jednoznacznych odpowiedzi;

- doświadczania satysfakcji z pokonywania przeszkód intelektualnych, rozwiązywania problemów; 
uczestniczenia w różnorodnych interakcjach z rówieśnikami: dyskusjach, argumentacjach, planowaniu zadań, wymianie poglądów, negocjowaniu konfliktów itp;

- wykorzystywania swoich umiejętności czytania i pisania w sposób celowy i przydatny życiowo (ważny osobiście);

- podejmowania inicjatywy i akceptowania odpowiedzialności za wykonane zadanie;

- doświadczania poczucia przynależności do grupy rówieśników;

- pomagania innym w odkrywaniu i lepszym rozumieniu świata;

- wyrażania uznania dla wysiłków i osiągnięć innych dzieci w grupie.

Jak podkreśla wielu badaczy, takie podejście wymaga przygotowania otoczenia wrażliwego na potrzeby dziecka oraz zaufania do jego możliwości intelektualnych (Brzezińska et al. 2012; Gruszczyk-Kolczyńska, Zielińska 1997).

Podsumowując, warto zauważyć, że idea edukacji STEM staje się coraz szerzej znana w polskiej pedagogice. Świadczą o tym zarówno nowe projekty, jak też nowe publikacje przybliżające nauczycielom zasady projektowania tego typu edukacji (Plebańska, Trojańska 2018; Plebańska, Szyller 2021; EETP 2019; Meritum 2019; Jakubowski, Piotrowski 2019).

\section{Bibliografia}

Brenneman, K. (2011). Assessment for preschool science learning and learning environments. „Early Childhood Research \& Practice”, 13(1). https://ecrp.illinois.edu/v13n1/brenneman.html (dostęp: 15.05.2021).

Brenneman K., Lange A., Nayfeld I. (2019). Integrating STEM into Preschool Education; Designing a Professional Development Model in Diverse Setting. „Early Childhood Education Journal" 57, s. 15-28, DOI: 10.1007/s10643-018-0912-z.

Bruner J.S. (2006), Kultura edukacji. Warszawa: PWN

Brzezińska A.I., Matejczuk J., Nowotnik A. (2012). Wspomaganie rozwoju dzieci w wieku od 5 do 7 lat a ich gotowość do radzenia sobie z wyzwaniami szkoty, „Edukacja” 1 (117), s. 7-22.

Clement, John (2000). Model based learning as a key research area for science education. „International Journal of Science Education”. 22 (9), s. 1041-1053. DOI: $10.1080 / 095006900416901$. S2CID 145367158.

Clements D.H., Sarama J. (2016), Math, Science, and Technology the Early Grades, „Future of Children" 26 (2), s. 75-94, <https://files.eric.ed.gov/fulltext/EJ1118544.pdf> (dostęp: 10.11.2019).

Dilek H., Tasdemir A, Konca A.S., Baltic S. (2020). Preschool Children's Science Motivation and Process Skills during Inquiry-Based STEM Activities, "Journal of Education in Science, Environment and Health" 6(2), DOI: 10.21891/jeseh.673901. 
Edukacja STEM - rozwijanie myślenia naukowego w przedszkolu (2019), „Edukacja Elementarna w teorii i Praktyce" 4(54), cały numer, https://czasopisma.ignatianum.edu. pl/eetp/issue/view/97 (dostęp: 15.11.2021).

Gruszczyk-Kolczyńska E., Zielińska E. (1997). Dziecięca matematyka. Edukacja matematyczna dzieci w domu, w przedszkolu i szkole. Warszawa: WSiP.

Jakubowski, R., Piotrowski, M. (2019). W poszukiwaniu uwarunkowań trwatego wprowadzenia STEM/STEAM w polskich szkotach. „Edukacja Elementarna w Teorii i Praktyce", 4(54), s. 25-37. https://doi.org/10.35765/eetp.2019.1454.02.

Katz L. G. (2010), STEM in early years. SEED papers. https://ecrp.illinois.edu/beyond/ seed/katz.html (dostęp: 22.07.2021).

Kennedy T.J., Odell M.R.L. (2014), Engaging Students in STEM Education, „Science Education International", 25(3), s. 246-258.

Kuhn D., Dean D. Jr, (2004), Metacognition: A Bridge Between Cognitive Psychology and Educational Practice, „Theory into Practice”, 43(4), 268-273. DOI: 10.1207/ s15430421tip4304_4

Mathematics and Science in Child Education (2021), „Edukacja Elementarna w Teorii i Praktyce" 16(3), cały numer, https://czasopisma.ignatianum.edu.pl/eetp/issue/ view/139 (data dostępu: 15.11.2021).

McClure E.R., Guernsey L., Clements D.H., Bales S.N., Nichols J., Kendall-Taylor N., Levine M.H., (2017), STEM Starts Early. Grounding science, technology, engineering, and math education in early childhood, The Joan Ganz Cooney Center at Sesame Workshop New America. <https://files.eric.ed.gov/fulltext/ED574402.pdf> (dostęp: 18.05.2018).

„Meritum. Mazowiecki Kwartalnik Edukacyjny” (2019/ 51). http://www.meritum.mscdn. edu.pl/numery/numer?id=56 (dostęp: 15.11.2021).

Plebańska M., Trojańska K. (2018), STEAM-owe lekcje. eBook:Wyd. eLitera.

Plebańska M., Szyller A. (2021), STEAM-owe przedszkole. Warszawa: Wyd. Difin.

Simoncini K., Lasen M. (2018). Ideas About STEM Among Australian Early Childhood Professionals: How Important is STEM in Early Childhood Education? „International Journal of Early Childhood" 50, s. 353-369.

White D.W. (2014), What is STEM education and why is it important, „Florida Association of Teacher Educators Journal", 1(14), s. 1-9, <http://www.fate1.org/journals/2014/ white.pdf> (dostęp: 12.07.2018).

Zdybel D. (2015). Metapoznanie - ukryty wymiar kompetencji kluczowych. [w:] Uszyńska-Jarmoc J., Bilewicz M. (red.). Kompetencje kluczowe dzieci i mtodzieży. Teoria i badania. Warszawa: Wydawnictwo Akademickie Żak, s. 54-70.

ADRES DO KORESPONDENCJI

Dorota Zdybel

Akademia Ignatianum w Krakowie e-mail: dorota.zdybel@ignatianum.edu.pl 